\title{
Impact of psychological capital on innovative performance and job stress
}

\section{Muhammad Abbas*}

Riphah International University

\author{
Usman Raja \\ Brock University
}

\begin{abstract}
We investigated the impact of psychological capital (PsyCap) on supervisory-rated innovative performance and job stress. Data collected from a diverse sample $(N=237$ paired responses) of employees from various organizations in Pakistan provided good support for the hypotheses. The results indicate that PsyCap is positively related to innovative job performance and negatively related to job stress. High PsyCap individuals were rated as exhibiting more innovative behaviours by their supervisors than low PsyCap individuals. Particularly, we found that high PsyCap individuals were more likely to generate, acquire support for, and implement novel ideas in their workplace. Similarly, individuals with high PsyCap reported lower levels of job stress as compared to their low PsyCap counterparts. Copyright (C) 2015 ASAC. Published by John Wiley \& Sons, Ltd.
\end{abstract}

Keywords: psychological capital, supervisory-rated innovative performance, job stress, Pakistan

\begin{abstract}
Résumé
Nous avons étudié l'impact du capital psychologique (PsyCap) sur la performance novatrice évaluée par un superviseur et le stress au travail. Les données collectées à partir d'un échantillon varié $(N=237$ réponses couplées) d'employés de plusieurs organisations au Pakistan ont amplement appuyé nos hypothèses. Les résultats montrent que le PsyCap est positivement relié à la performance novatrice au travail et négativement relié au stress professionnel. Les superviseurs estiment que les employés ayant un PsyCap élevé ont des comportements plus novateurs que les personnes ayant un PsyCap faible. De façon plus spécifique, l'étude révèle que les personnes qui ont un PsyCap élevé sont plus susceptibles de générer, de faire appuyer et de mettre en œuvre des idées novatrices à leur lieu de travail. Par ailleurs, ces personnes affirment avoir de faibles niveaux de stress professionnel comparativement à leurs collègues qui ont un PsyCap faible.
\end{abstract}

Mots-clés : capital psychologique, performance novatrice évaluée par un superviseur, stress professionnel, Pakistan
In order to gain a competitive advantage in today's highly competitive global environment, firms must be innovative (McAdam \& Keogh, 2004). Particularly, employee innovative behaviours (e.g., developing, adopting, and implementing new ideas for products and work methods) are important resources that make an organization successful in dynamic business environments (Yuan \& Woodman, 2010). Moreover, organizations require innovative people to sustain their competitive positions in the market (Zhou \& Shalley, 2008). Keeping in mind the importance of innovations for organizational sustainability, extant research has focused on contextual (Amabile, 1988; Carson \& Carson, 1993) as well as dispositional (Furnham \& Bachtiar, 2008; Tierney \& Farmer, 2002) factors that stimulate innovative behaviours in the workplace.

*Please address correspondence to: Muhammad Abbas, Faculty of Management Sciences, Riphah International University, Sector I-14, Islamabad Pakistan. Email: pirthegreat@gmail.com; muhammad.abbas@riu.edu.pk
Another main concern of organizations in the current changing environment is the increased possibility of job stress at work. Organizations unable to promise job security cannot in turn expect more loyalty and creativity from employees. Fiercely competitive environments where employees are constantly under pressure to improvise and innovate lead to job stress. Stress then leads to a variety of psychological and physiological problems among employees (Revicki \& May, 1985; Zhong et al., 2009). Further, job stress is considered a major contributor to health-related issues in organizations today, resulting in billions of dollars in the form of lost productivity and medical expenses (Cartwright \& Cooper, 1997; Robertson, Cooper, Williams, \& Williams, 1990). Occupational stress-related costs were estimated at billions of dollars per year in the US alone (Conti \& Burton, 1994; Greenberg et al., 2003). This has made job stress an important variable of interest in organizational research over the past few decades. Researchers are constantly trying to identify variables that either induce stress or are helpful in reducing the detrimental effects of stress. 
Psychological capital (PsyCap), which refers to an individual's positive psychological resources (Luthans, Youssef, $\&$ Avolio, 2007), is one such variable that, theoretically, is relevant to both innovation and stress. It can potentially provide a necessary repository of psychological resources that help effectively innovate work-related ideas and reduce job stress. Derived from positive organizational behaviours, PsyCap is composed of four components including hope, efficacy, resilience, and optimism. PsyCap has been found to be related to various important job outcomes such as job performance, organizational commitment, job satisfaction, and turnover intentions (Abbas, Raja, Darr, \& Bouckenooghe, 2014; Luthans, Norman, Avolio, \& Avey, 2008).

Although several studies have recently investigated the relationship between PsyCap and creativity (Luthans, Youssef, \& Rawski, 2011; Rego, Sousa, \& Marques, 2012; Sweetman, Luthans, Avey, \& Luthans, 2011), they all used exercises and scales that were restricted to the idea generation phase of innovation and had less relevance to jobrelated innovative performance. In addition, Luthans et al. (2011) relied on self-reports for both psychological capital and creativity, while Sweetman et al. (2011) recognized the limitations of focusing on the idea generation phase and called upon future research to draw from an alternative measure of creative performance.

Creativity refers to behaviours pertaining to the generation of novel and useful ideas (Amabile, 1988; Oldham \& Cummings, 1996), whereas innovative behaviours include not only the generation of new ideas but also the adoption of others' ideas that are new to one's organization or work unit (Woodman, Sawyer, \& Griffin, 1993; Yuan \& Woodman, 2010). Although creative performance or creativity is closely linked to innovative behaviours, creativity is only a starting point. Innovation, on the other hand, includes the different steps for the successful implementation of creative ideas within an organization at different levels (Yuan \& Woodman, 2010). An individual's innovative behaviours are the composite of complex behavioural tasks including idea generation, idea promotion, and idea realization (Janssen, 2001; Kanter, 1988; Scott \& Bruce, 1994). Scholars have suggested that all types of innovations start with the idea generation phase, which involves the generation of novel and useful ideas in any domain (Woodman et al., 1993). The next phase is idea development, which involves mobilizing support and acquiring approvals for the idea from peers and/or supervisor(s) (Kanter, 1988). The last phase relates to idea realization, which is the transformation of these ideas into useful applications within a work role or group, or within the entire organization (Kanter, 1988). These behaviours are demonstrated in the different stages of development and are characterized by discontinuous activities (Kanter, 1988). In addition, individuals may be involved in any combination of these behaviours at any time (Scott \& Bruce, 1994). Therefore, by not considering a more composite measure of individuals' innovative behaviours, the current evidence on PsyCap and creativity may be inconclusive.

Similarly, although research shows PsyCap is related to job stress, the number of studies examining this relationship is limited. More importantly, our insight into the efficacy of psychological resources in reducing stress in newer contexts such as that of Pakistan is even more so limited. Therefore, it is essential to investigate the viability of PsyCap as a predictor of reduced stress in newer work settings. Both job stress and innovative performance are high impact variables in organizations such that even a small variation in these could translate into an enormous amount of revenue for organizations. For example, just a two percent variance in stress or innovation in an organization with 500 employees translates into 10 employees being either stressed or innovative. The high impact of stress on losses in individual productivity or the even more severe outcomes associated with depression make even a small variance in it very important. Similarly, innovation is something that defines the survival of an organization in today's competitive environment, which makes it very important to focus on factors that could provide organizations with a marginal edge over their competitors in terms of capacity to innovate.

Finally, researchers have emphasized the importance of conducting innovation-related research "among organizations in emerging economies," particularly in Asian settings (Drazin \& Schoonhoven, 1996, p. 1081). For example, Bartram and Rimmer (2012, p. 1) have noted that "the economic dominance of China and India and their near neighbors has triggered enormous curiosity among HR researchers." Until these theories are tested in non-US settings, HR researchers will have little confidence in the generalizability of these models. In fact, management scholars recently have called for ample testing and replication of existing theories to develop a reliable body of knowledge that can be used by managers for "evidence based decision [s]" (Hambrick, 2007; Pfeffer \& Sutton, 2006). Our study responds to these calls and extends the theory of PsyCap to an Eastern context (i.e., Pakistan), thereby providing external validity to the findings of research in Western contexts. Using the framework of Fredrickson's (2004) broaden-andbuild theory, we examine the impact of positive PsyCap on supervisory-rated innovative performance and job stress in Pakistan.

\section{Theory and Hypotheses}

\section{Psychological Capital}

In recent years, organizational behaviour research has significantly shifted from seeing individuals as coping with weaknesses to seeing them as able to enhance their strengths and wellbeing in the workplace (Cameron \& Caza, 2004; Wright, 2003). Seligman and Csikszentmihalyi (2000) 
posited that "[n]o longer do the dominant theories view the individual as a passive vessel 'responding' to 'stimuli'; rather, individuals are now seen as decision makers, with choices, preferences, and the possibility of becoming masterful, efficacious, or, in malignant circumstances, helpless and hopeless" (p. 8).

Derived from this line of thinking, PsyCap has emerged as a positively oriented higher-order construct (Luthans \& Youssef, 2007). This higher-order PsyCap is defined as:

an individual's positive psychological state of development and is characterized by: (1) having confidence (self-efficacy) to take on and put in the necessary effort to succeed at challenging tasks; (2) making a positive attribution (optimism) about succeeding now and in the future; (3) persevering toward goals and, when necessary, redirecting paths to goals (hope) in order to succeed; and (4) when beset by problems and adversity, sustaining and bouncing back and even beyond (resilience) to attain success (Luthans, Youssef, et al., 2007, p. 3).

Positive PsyCap has been found to be related to various job outcomes such as job performance, job satisfaction (Abbas et al., 2014; Luthans, Avolio, Avey, \& Norman, 2007), turnover intentions (Avey, Luthans, \& Youssef, 2010), and cynicism (Avey, Wernsing, \& Luthans, 2008). Although the majority of the studies on PsyCap have been conducted in North America, particularly in the US, there are a handful of studies that have examined the impact of various components of PsyCap on job outcomes in non-US settings (Abbas et al., 2014; Luthans, Combs, Clapp-Smith, $\&$ Nadkarni, 2006).

\section{Psychological Capital and Innovative Behaviours}

Although some recent studies have examined the impact of a variety of psychological resource capacities on creativity, these resources have been separately linked with creativity or innovation-related outcomes. For example, Rego, Machado, Leal, and Cunha (2009) investigated the relationship between hope and creativity, while Rego, Sousa, Marques, and Cunha (2012) examined the relationship between optimism and creativity. Similarly, Tierney and Farmer (2002) investigated the relationship between efficacy and creative performance.

Research suggests that the positive psychological resources of efficacy, hope, resilience, and optimism have the potential to trigger innovative behaviours in the workplace. However, these resources do not act in isolation. Instead, they provide support for each other through an underlying shared mechanism (Fredrickson, 2001; Hobfoll, 2002; Magaletta \& Oliver, 1999); hence, they should be studied collectively (Abbas et al., 2014; Luthans, Avolio, et al., 2007). Empirical research also supports the notion that studying PsyCap as a core construct predicts job outcomes better than any of its individual components (Luthans, Avolio, et al., 2007; Sweetman et al., 2011).
As mentioned above, positive PsyCap is characterized by the presence of hope, optimism, efficacy, and resilience. Hope involves the willpower to perform creatively and the waypower for the creative exploration of multiple pathways to reach a goal (Luthans, Youssef, et al., 2007). According to Snyder, Lapointe, Crowson, and Early (1998), high hope individuals use agentic (goal directed) thinking to move along a pathway and continue to progress. This agentic and pathway thinking is iterative in nature (see Snyder, Harris, et al., 1991).

Hope has been found to be associated with academic and athletic performance, as well as mental and physical health (Snyder, Irving, \& Anderson, 1991). In addition, high hope individuals tend to be independent thinkers (Luthans, Youssef, et al., 2007). Hopeful individuals take risks and look for alternative pathways when old ones are blocked (Snyder, 1994). Hopeful employees "tend to be creative and resourceful, even with tight budgets" (Luthans, Youssef, et al., 2007, p. 74). These individuals actively work on creative ideas for solving problems, and they regard problems and opportunities from different angles (Zhou \& George, 2003). Because of their ability to generate alterative pathways and their creative approaches to tasks, high hope individuals are likely to generate and apply innovative ideas in the workplace.

Similarly, optimism is positively associated with mental health (Seligman, 1998). Optimists tend to maintain positive expectations about results (Avey et al., 2008), and Rego, Sousa, Marques, and Cunha (2012) found that optimistic individuals also tend to be more creative. Optimistic leaders pursue new and creative approaches towards problem solving (Peterson, Walumbwa, Byron, \& Myrowitz, 2008). Moreover, optimists tend to take credit for and expect positive events in their lives while distancing themselves from unfavourable life events. Hence, it is less likely that these individuals will experience self-blame and despair when working on innovative solutions for their problems. Therefore, we expected that optimism will help individuals generate and apply innovative approaches in the accomplishment of their tasks.

In a similar vein, Stajkovic and Luthans (1998) and Bandura and Locke (2003) found that self-efficacy had a strong positive relationship with work-related performance. According to Bandura and Locke (2003), self-efficacy helps with perseverance in the face of obstacles. Efficacious individuals are inventive, resourceful (Bandura, 1986), and creative (Tierney \& Farmer, 2002). Therefore, we expected highly efficacious individuals to be more likely to generate and apply innovative ideas in their workplace.

Finally, resilience helps individuals become flexible and adaptable during highly uncertain situations (Coutu, 2002). Resilient individuals are optimistic, energetic towards life, curious, and open to new experiences (Block \& Kremen, 1996). These individuals are also humorous (Wolin \& Wolin, 1993) and use creative exploration (Cohler, 1987). Resilient individuals elicit positive emotions in themselves as well as in others (Fredrickson, 2004), which may help them create a supportive environment that facilitates 
innovative behaviours. Resilient leaders are likely to encourage themselves and even their subordinates to take risks and exhibit innovative behaviours (Peterson et al., 2008). Therefore, it is likely that resilience helps individuals apply innovative approaches to their work, acquire support for new ideas, and bounce back when faced with difficulties in the implementation of new ideas.

Together, high PsyCap individuals are thought to put forth intentional efforts to produce creative ways of attaining goals. Being relevant to positive organizational change, PsyCap is considered an individual-level higher-order factor that facilitates change (Avey et al., 2008). Individuals high on PsyCap are able to develop new pathways (hope) to attain their goals. These individuals possess the confidence (efficacy) necessary to arrive at desired goals using alternative paths (hope), have positive attribution and outlook for the future (optimism), and are able to bounce back from setbacks (resilience) in the case of any difficulty or failure that may arise due to the implementation of innovative ideas (Avey et al., 2008; Luthans et al., 2007). It follows that these positive psychological resource capacities may help employees exhibit innovative behaviours by broadening the options they perceive and helping them exert effort to reach goals using their willpower and waypower, even in the face of initial failure and setbacks.

In a similar vein, we draw on broaden-and-build theory (Fredrickson, 2001) to explain the relationship between PsyCap and innovative performance. Past research on positive PsyCap has also used the broaden-and-build framework to understand the effects of positive PsyCap on a variety of job outcomes (Avey, Reichard, Luthans, \& Mhatre, 2011; Norman, Avey, Nimnicht, \& Pigeon, 2010; Walumbwa, Peterson, Avolio, \& Hartnell, 2010).

According to broaden-and-build theory, positive emotions share the capacity to broaden people's momentary thought-action repositories and widen the array of thoughts and actions that come to their minds (Bakker \& Demerouti, 2008; Fredrickson, 2001), thereby increasing the potential for the demonstration of innovative behaviours such as sharing creative ideas and providing suggestions for improvements at work (Avey, Luthans, \& Youssef, 2010; Avey, Reichard, et al., 2011). This theory further posits that positive emotions and orientations broaden people's attention and focus as well as their patterns of thinking (Fredrickson, 2001; Isen, 2000; Kahn \& Isen, 1993). These emotions and orientations also help individuals make connections between divergent stimuli (Isen, 1999) and therefore can be expressed as innovative behaviours (Avey et al., 2011).

Research on PsyCap suggests that PsyCap contributes to positive emotions. Avey et al. (2008) found that hope, optimism, efficacy, and resilience produce positive emotions among individuals while Avey, Wernsing, and Mhatre (2011) also found PsyCap to be a source of positive emotions. Therefore, it is possible that positive PsyCap of hope, efficacy, optimism, and resilience use positive emotions to develop broader thought-action repertoires that are manifested as innovative performance. The broadened inventory of positive psychological resources such as hope, efficacy, optimism, and resilience may be helpful in problem solving and enhancing creativity since employees with a positive mindset are more creative (Luthans et al., 2011; Rego, Sousa, and Marques, 2012). Employees with a positive mindset may not only be able to generate innovative ideas but may also acquire approvals from colleagues to support their ideas and transform them into useful applications in the workplace.

Together, these psychological resources have cognitive, affective, motivational, and decisional components (Bandura \& Locke, 2003; Peterson, 2000) that help employees successfully develop and implement work-related innovative ideas. Besides, high PsyCap individuals possess the cognitive capacity of self-regulation (Bandura, 1991), which provides the initiative, pro-activeness, and self-discipline necessary for reaching their goals (Luthans \& Youssef, 2007). Overall, high PsyCap individuals have a built-in creative tendency to develop multiple pathways to accomplish their goals and invest their efforts in generating, promoting, and realizing job-related innovative behaviours. Consequently, we hypothesized:

\section{H1: Psychological capital is positively related to inno- vative performance.}

\section{Psychological Capital and Job Stress}

Past research suggests that the PsyCap components of hope, efficacy, resilience, and optimism are positive psychological resources that collectively act as "a solid resource reservoir" (Hobfoll, 2002, p. 318). Individuals with a greater pool of such resources are less likely to experience job stress. Social psychologists have suggested that these positive psychological resources provide support to each other through an underlying shared mechanism (Fredrickson, 2001; Youssef \& Luthans, 2007) that binds them together, broadens momentary thought-action repertoires, and helps individuals experience low job stress (Hobfoll, 2002).

The hope component of PsyCap has been found to be associated with mental and physical health, and an ability to cope with adversity (Snyder et al., 1991). Optimism is negatively associated with depression and positively associated with mental health (Seligman, 1998). Optimists continue to work hard and actively manage the problems they face while pursuing desirable outcomes (Kluemper, Little, \& DeGroot, 2009). Similarly, research suggests that highly efficacious individuals experience low job stress and burnout (Salanova, Peiró, \& Schaufeli, 2002). According to Bandura and Locke (2003), self-efficacy beliefs help individuals persevere in the face of obstacles and cope with distressing and self-debilitating emotional states that hinder the execution of activities. Moreover, resilient individuals 
have the ability to adapt positively when faced with risk and adversity (Masten \& Reed, 2002).

According to broaden-and-build theory, positive emotions share the capacity to broaden people's momentary thought-action repositories, widen the array of thoughts and actions that come to their minds, and provide a positive outlook of the external environment (Bakker \& Demerouti, 2008; Fredrickson, 2001), thereby helping individuals avoid experiencing high stress (Siu, Cheung \& Lui, 2014). Studies suggest that the broadened inventory of positive psychological resources, such as hope, efficacy, optimism, and resilience, may be helpful in promoting low stress (Ong, Bergeman, Bisconti, \& Wallace, 2006; Tugade \& Fredrickson, 2004). Avey, Luthans, and Jensen (2009) found PsyCap to be a positive resource that combats occupational stress. These positive psychological resources possess cognitive, affective, and motivational components (Bandura \& Locke, 2003; Peterson, 2000) that keep individuals away from stress.

Taken together, high PsyCap individuals, being confident in their beliefs and hopeful, optimistic, and highly resilient in the face of obstacles, are less likely to report job stress. Consequently, we hypothesized:

\section{H2: Psychological capital is negatively related to job stress.}

\section{Methods}

\section{Sample and Data Collection Procedures}

The data were collected through the personal administration of questionnaires at private banks, local offices of textile firms, offices of a government ministry, and the customer service offices of a telecommunication company in Faisalabad, which is the third largest city in Pakistan. Of the 237 complete responses, about $17 \%$ of the surveys were received from government workers, $50 \%$ from bank branches, $21 \%$ from textile firms, and the remaining received from the telecom company. As English is the medium of instruction at the college and university level and people in Faisalabad read and understand English, we did not translate the questionnaires into the local language.

We used personal and professional contacts to gain entry permission from the concerned organizations. The questionnaires included a cover letter explaining the purpose of the study to the respondents and assuring them of strict confidentiality. No significant events took place during the collection of data in these organizations. The participation was voluntary and respondents completed a self-report version of the questionnaire, which included the measures of PsyCap and job stress. The respondents also reported their gender, age, occupational level, education, and work experience. The supervisor of each respondent completed the supervisor-report version, which contained questions on innovative performance. The questionnaire was completed by the respective supervisor of each respondent. Both the respondents and their supervisors separately returned the completed surveys to one of the authors without having access to each other's responses.

We distributed 300 questionnaires, of which 237 usable paired (self and supervisor-report) responses were received for a response rate of $79 \%$. The majority of respondents $(79 \%)$ were male, the average age was $31(S D=8.03)$ years, and the average tenure was $4.80(S D=6.43)$ years. The sample represents several occupational levels including $16 \%$ entry level workers (clerical and technical staff), $80 \%$ supervisory and middle managers, and $4 \%$ upper-middle and top-level managers, with education levels ranging from 14 years of education to graduate degrees including MBAs.

\section{Measures}

Psychological capital and job stress were measured using self-reports. However, to avoid self-report bias issues, innovative performance was measured using supervisoryreports. Higher responses obtained against a variable represent a higher level of that construct. The following questionnaires were used for the collection of data.

Psychological capital. PsyCap was measured by a 24item Psychological Capital Questionnaire (PCQ: Luthans, Youssef, et al., 2007). Examples of the items include, "I feel confident analyzing a long-term problem to find a solution," "If I should find myself in a jam at work, I could think of many ways to get out of it," "When I have a setback at work, I have trouble recovering from it, moving on," and "When things are uncertain for me at work, I usually expect the best." The responses for PsyCap were taken using a 6-point Likert-scale with anchors of $1=$ "Strongly disagree" through to 6 = "Strongly agree."

Psychological capital has been theorized and operationzed as a higher-order latent construct in previous studies; therefore, we conducted a second-order Confirmatory Factor Analysis (CFA) to see if all four dimensions loaded onto a single latent factor. The results yielded a good fit for a latent single-factor model $(\chi 2=437.90, \mathrm{df}=244$, comparative fit index $[\mathrm{CFI}]=.88$, goodness-of-fit index $[\mathrm{GFI}]=.87$, incremental fit index $[\mathrm{IFI}]=.89$, and root mean square error of approximation $[$ RMSEA] $=.05$ ). Therefore, to create an overall PsyCap, we averaged the scores on all 24 items such that a high score reflects high PsyCap. The internal consistency reliability of PsyCap was $\alpha=.83$.

Innovative performance. Supervisory-rated innovative performance was measured using six items from the Janssen's (2001) scale for individual innovative behaviour in the workplace that is based on Kanter's (1988) work on stages of innovation and covers several necessary phases (i.e., idea generation, idea promotion, and idea realization) of individuals' innovative behaviours. Two items each on this questionnaire assessed idea generation, idea promotion, and idea realization. Sample items included "Generates 
original solutions to problems," "Mobilizes support for innovative ideas," and "Transforms innovative ideas into useful applications." The responses for innovative performance were taken using a 7-point Likert-scale with anchors $1=$ "Never," through to 7 = "Always."

Previous research shows that these three dimensions combine additively to create an overall scale of individual innovative behaviour (Janssen, 2001, 2004); therefore, we conducted a second-order confirmatory factor analysis (CFA) to see if the 3-dimensional construct did load onto a single latent factor. The results of the CFA revealed a good fit for a latent single-factor model $(\chi 2=8.63, \mathrm{df}=6$, comparative fit index $[\mathrm{CFI}]=.99$, goodness-of-fit index $[\mathrm{GFI}]=.98$, incremental fit index $[\mathrm{IFI}]=.99$, and root mean square error of approximation [RMSEA] $=.04)$. Therefore, we used an additive measure by taking the average of all items to create an overall innovative performance score such that high scores reflect high innovative performance. The reliability of the innovative performance measure was $\alpha=.89$.

We also conducted additional analyses to see if PsyCap significantly predicts all three phases of innovative performance (i.e., idea generation, idea promotion, and idea realization). For this purpose, we conducted a three-factor CFA for innovative performance. The results of the CFA revealed a good fit for a three-factor model. These results were almost identical to the result for the latent single-factor model $(\chi 2=8.63, \mathrm{df}=6$, comparative fit index $[\mathrm{CFI}]=.99$, goodness-of-fit index $[\mathrm{GFI}]=.98$, incremental fit index $[\mathrm{IFI}]=.99$, and root mean square error of approximation $[$ RMSEA] $=.04)$.

Job stress. Job stress was measured by a shortened version (9 items) of the original 13-item Job Stress Scale developed by Parker and DeCotiis (1983). The shortened version was previously used by Jamal and Baba (1992). This scale was used because of its good psychometric properties as reported in recent studies conducted in Western settings (Burton, Hoobler, \& Scheuer, 2012; Hunter, \& Thatcher, 2007) and in Pakistan (Jamal, 2007, 2010). The items include "Sometimes when I think about my job I get a tight feeling in my chest" and "I have too much work and too little time to do it in." The reliability of this scale is $\alpha=.71$. Responses for job stress were taken using a 5-point scale with anchors of $1=$ "strongly disagree," through to 5 = "strongly agree."

Control variables. We included age, gender, and organization type as controls for all outcomes. Past research suggests that creativity (Furnham \& Bachtiar, 2008; Lau, \& Cheung, 2010; Wu, Cheng, Ip, \& McBride-Chang, 2005) and job stress (Antoniou, Polychroni, \& Vlachakis, 2006) may vary across gender and different age groups; therefore, age and gender were included as control variables. Further, a one-way ANOVA comparing innovative performance and job stress across organizations and occupational levels revealed that significant differences in job stress $(F=5.42, p<.02)$ were found for different organization types. In addition, the post-hoc analysis revealed that the differences were only between the 1 public sector and 3 private sector organizations. The post-hoc further revealed that the average level of job stress in private organizations was higher than the average job stress in public organizations. Hence, we created a dummy variable $(0=$ "Private," $1=$ "Public $)$ to control for the effects of organization type.

\section{Results}

Table 1 shows the means, standard deviations, bivariate correlations, and estimates of reliability (coefficient alpha). The zero-order bivariate correlations between PsyCap, job stress, and innovative performance were in the expected direction. Psychological capital was negatively related to job stress $(r=-.15, p<.05)$ and positively related to innovative performance $(r=.20, p<.01)$. In addition, PsyCap was positively and significantly related to idea generation $(r=.17, p<.01)$, idea support $(r=.18, p<.01)$, and idea implementation $(r=.17, p<.01)$.

Multiple regression analysis was used to test all the main effect hypotheses. Age, gender, and organizational type (control variables) were entered in the first step followed by the independent variable. Table 2 presents the regression results for the effect of PsyCap on job stress and innovative performance. The results revealed that PsyCap was positively related to innovative performance $(\beta=.21$, $\left.p<.001 ; \Delta R^{2}=.04, p<.001\right)$ and negatively related to job stress $\left(\beta=-.13, p<.05 ; \Delta R^{2}=.02, p<.05\right)$. These results render support for $H 1$ and $H 2$. Moreover, PsyCap explained $4 \%$ additional variance in innovative performance and $2 \%$ additional variance in job stress.

We also conducted a dimension-wise analysis for innovative performance. The control variables were entered in the first step, followed by the independent variable. Table 3 presents the regression results for the effect of PsyCap on the three phases of innovative performance. The results suggest that PsyCap is positively related to idea generation $(\beta=.18$, $\left.p<.01 ; \Delta R^{2}=.03, p<.01\right)$, idea support $(\beta=.19, p<.01$; $\left.\Delta R^{2}=.04, p<.01\right)$, and idea implementation $(\beta=.17$, $\left.p<.05 ; \Delta R^{2}=.02, p<.05\right)$. These results provide evidence that PsyCap significantly predicts all phases of innovative behaviours including idea generation, idea support, and idea implementation.

\section{Discussion and Conclusion}

\section{Summary}

We tested for the main effects of PsyCap on employee innovative performance and job stress. Consistent with Sweetman et al. (2011), our findings clearly support the assertion that individuals who are high in PsyCap are more 
Table 1

Means, Standard Deviations, Correlations, and Reliabilities

\begin{tabular}{|c|c|c|c|c|c|c|c|c|c|c|c|}
\hline & Mean & S.D & 1 & 2 & 3 & 4 & 5 & 6 & 7 & 8 & 9 \\
\hline 1. Gender & 1.20 & .40 & - & & & & & & & & \\
\hline 2. Age & 30.71 & 8.03 & $-27 * *$ & - & & & & & & & \\
\hline 3. Organization type & .16 & .372 & $-14 *$ & $.37 * *$ & - & & & & & & \\
\hline 4. Job stress & 2.94 & .58 & -.10 & -.06 & $-.15^{*}$ & $(.71)$ & & & & & \\
\hline 5. Innovative performance & 4.53 & 1.09 & -.01 & -.05 & -.06 & -.09 & $(.89)$ & & & & \\
\hline 8. Idea implementation & 4.39 & 1.31 & -.04 & .04 & .03 & -.06 & $.86 * *$ & $.63 * *$ & $.58 * *$ & $(.81)$ & \\
\hline 9. Psychological capital & 4.31 & .56 & .01 & .02 & $.16^{*}$ & $-.15 *$ & $.20 * *$ & $.17 * *$ & $.18 * *$ & $.17 * *$ & $(.83)$ \\
\hline
\end{tabular}

Note. $N=237$; Cronbach's alphas presented in parenthesis; for organizational type, $0=$ "Private" and $1=$ "Public"; gender was coded as " 1 " for male and " 2 " for female.

$* p<.05, * * p<.01$

\section{Table 2}

\section{Regression Results for Psychological Capital, Innovative Performance, and Job Stress}

\begin{tabular}{|c|c|c|c|c|}
\hline & \multicolumn{2}{|c|}{ Innovative performance } & \multicolumn{2}{|c|}{ Job stress } \\
\hline & $\beta$ & $\Delta \mathrm{R}^{2}$ & $B$ & $\Delta \mathrm{R}^{2}$ \\
\hline \multicolumn{5}{|l|}{ Step 1: } \\
\hline Gender & -.02 & & $-.13 *$ & \\
\hline Age & -.03 & & -.04 & \\
\hline Organization type & -.05 & .01 & $-.16^{*}$ & $.04 *$ \\
\hline \multicolumn{5}{|l|}{ Step 2: } \\
\hline Psychological capital & $.21 * *$ & $.04 * *$ & $-.13 *$ & $.02 *$ \\
\hline
\end{tabular}

Note. $N=237$; Standardized Coefficients are reported. For organizational type, $0=$ "Private" and $1=$ "Public"; gender was coded as " 1 " for male and " 2 " for female.

$* \mathrm{p}<.05 ; * * \mathrm{p}<.001$

likely to exhibit innovative behaviours in the workplace than their low PsyCap counterparts. Our results reveal that high PsyCap individuals, due to their natural tendency towards exhibiting innovative behaviours, take initiatives in the generation, promotion, and realization of new ideas in their work roles. Our findings also reveal that individuals with high PsyCap report lower job stress than individuals with low PsyCap. This suggests that high PsyCap individuals, because of their positive orientation and resilient approach towards the external environment, are able to handle stress well.

Despite its theoretical appeal and importance in today's workplace, no previous study has investigated the relationship between PsyCap and supervisory-rated innovative job performance. The current study provides an extension to the theory of PsyCap by exploring its link with employees' innovative performance and job stress. In addition, the study
Table 3

Regression Results for Psychological Capital and Phases of Innovative Performance

\begin{tabular}{|c|c|c|c|c|c|c|}
\hline & \multicolumn{2}{|c|}{$\begin{array}{c}\text { Idea } \\
\text { generation }\end{array}$} & \multicolumn{2}{|c|}{$\begin{array}{l}\text { Idea } \\
\text { support }\end{array}$} & \multicolumn{2}{|c|}{$\begin{array}{c}\text { Idea } \\
\text { implementation }\end{array}$} \\
\hline & B & $\Delta \mathrm{R}^{2}$ & $\beta$ & $\Delta \mathrm{R}^{2}$ & B & $\Delta \mathrm{R}^{2}$ \\
\hline \multicolumn{7}{|l|}{ Step 1: } \\
\hline Gender & -.02 & & .00 & & -.03 & \\
\hline Age & -.06 & & -.06 & & .03 & \\
\hline $\begin{array}{l}\text { Organization type } \\
\text { Step 2: }\end{array}$ & -.08 & .01 & -.07 & .01 & .01 & .00 \\
\hline $\begin{array}{l}\text { Psychological } \\
\text { capital }\end{array}$ & $.18^{* *}$ & $.03 * *$ & $.19 * *$ & $.04 * *$ & $.17 *$ & $.02 *$ \\
\hline
\end{tabular}

Note. $N=237$; Standardized Coefficients are reported. For organizational type, $0=$ "Private" and $1=$ "Public"; gender was coded as " 1 " for male and " 2 " for female.

$* \mathrm{p}<.05 ; * * \mathrm{p}<.01$

tests the PsyCap theory, predominantly developed and tested in Western settings, in an Eastern setting and therefore provides external validity to this theory. With the exception of a few studies (Combs, Clapp-Smith, \& Nadkarni, 2010; Luthans et al., 2006), the majority of the previous studies on PsyCap, including the study by Sweetman et al. (2011), have been conducted in North American settings. Recently, Avey et al. (2011) conducted a meta-analytic study and found that the correlations for PsyCap and a variety of work-related outcomes were stronger in US samples as opposed to non-US samples. These authors called for future research to examine the relative influence of PsyCap on other important job outcomes across cultures.

As a result, a comparison of the zero-order correlations reported in Table 1 against the studies conducted in US 
settings provides an opportunity to compare the results for main effects in Western cultures to those examined in this study. Unfortunately, we were unable to compare our observed correlations for PsyCap and job stress with the meta-analytic associations reported by Avey et al. (2011) because these authors did not compare the bivariate correlations across countries separately for each outcome. In addition, these authors did not include any study examining the association between PsyCap and innovative behaviour. In another recent study, Luthans et al. (2011) examined the impact of PsyCap on innovation. Unfortunately, these authors did not report the bivariate correlations in their study; therefore, we could not compare the effect size for PsyCap and innovative performance observed in our study with Luthans et al.'s (2011) findings.

Finally, we compared our observed associations for PsyCap and innovative performance against the correlations reported by Sweetman et al. (2011). It appears that the correlations observed in our study were relatively weaker $(r=.20$, $p<.01)$ than those observed by Sweetman et al. (2011) in a US sample $(r=.25, p<.001)$. The results for the associations of PsyCap with all phases of innovative performance were also relatively weaker in our study compared to those reported by Sweetman et al.

For job stress, we compared the correlations observed in our study with those observed by Avey et al. (2009). The zero-order bivariate correlations in our study $(r=-.15, p$ $<.05)$ were relatively weaker than those found by Avey et al. (2009) in the US sample $(r=-.35, p<.001)$. These comparisons suggest that the effects of PsyCap on innovative performance and job stress, although significant, are weaker in Pakistani settings than in US settings. These findings are consistent with the meta-analytic findings of Avey et al. (2011) who found that the effects of PsyCap on a variety of job outcomes were stronger in US settings than nonUS settings. That said, our results suggest that PsyCap, in general, has a negative effect on job stress and a positive effect on innovative job performance. In other words, consistent with the Fredrickson's (2001) broaden-and-build theory, the results of this study suggest that the broadened thought-action repertoires and expanded inventory of positive psychological resources have the capacity to enhance innovative performance and reduce job stress. Our findings further suggest that the results from past research in Western settings generalize well to the Pakistani context, which suggests that PsyCap is perhaps personal in nature and less context dependent (Abbas et al., 2014).

Our study also provides further evidence of the effect of PsyCap on all dimensions of innovative performance. Our findings suggest that PsyCap significantly affects all phases of innovative behaviours including idea generation, idea support, and idea implementation. In other words, individuals with high PsyCap cannot only generate new ideas but are also able to mobilize support for innovative ideas and implement those ideas in the workplace.

\section{Contributions to Scholarship}

Our study extends the theory of PsyCap to an Eastern context (i.e., Pakistan) and provides external validity to the findings of research in Western contexts. Using the framework of Fredrickson's (2004) broaden-and-build theory, we examined the impact of positive PsyCap on supervisory-rated innovative performance and job stress in Pakistan.

Past research on PsyCap and creativity focused only on the idea generation phase of innovative work behaviours. Our study used a more composite measure of innovative performance. The findings suggest that PsyCap significantly affects all phases of innovative behaviours including idea generation, idea support, and idea implementation. These findings support the broaden-and-build theory (Fredrickson, 2001) and suggest that positive psychological resources broaden the thought-action repertoires and help individuals to generate, mobilize, and implement innovative ideas in their workplace. We also found that individuals with high PsyCap experienced low levels of job stress.

In addition, we compared the bivariate correlations observed in our study with those reported in past studies conducted in Western settings. The correlations observed in our study were relatively weaker than those observed in the previous studies. These findings are consistent with the meta-analytic findings of Avey et al. (2011) who found that the effects of PsyCap on a variety of job outcomes were stronger in US settings than in non-US settings.

\section{Applied Implications}

This study also has implications for practicing managers. Since PsyCap is composed of state-like resource capacities and is open to development (Luthans, Avey, \& Patera, 2008), managers can develop their employees' PsyCap through various training interventions. This will help employees foster new and innovative ways of accomplishing their tasks. High PsyCap individuals, due to their positive psychological resources, may offer a competitive advantage to their organizations. Managers should also be careful with regards to assigning relatively stressful tasks to those who are low on PsyCap as these individuals are more likely to experience job stress.

\section{Limitations and Future Research Directions}

There are several limitations to the current study. As with most research, there is a possibility of method bias since PsyCap and job stress were measured using self-reports. However, this should not be an issue in the case of innovative performance as it was measured using supervisory-rated responses. Second, we did not measure other relevant personality factors such as proactive personality and openness to experience, which may affect innovative performance; 
therefore, we were unable to examine the relative strength of PsyCap. Future research can address this by comparing the predictive ability of PsyCap with other creativity-related personality traits. A comparison of PsyCap with other personality traits in predicting creative behaviours would help in understanding the relative strength of positive PsyCap.

Recently, Byron, Khazanchi, and Nazarian (2010) conducted a meta-analytic study and tested the effects of work-related stressors on creativity. These authors found that uncontrollable stressors had a negative effect on creativity, whereas controllable stressors had a positive effect. Future research should examine the buffering or exacerbating role of positive PsyCap in predicting creativity in the face of work stressors.

We collected data from a diverse sample of employees working in banks, a government ministry, a telecommunications firm, and textile firms. Although innovation may not be as highly desirable in these industries as in high-tech firms, the generation and implementation of new ideas and methods of improvement is required for nearly all jobs (Shalley \& Gilson, 2004) and all organization types (Damanpour, 1991; Lyons, Chatman, \& Joyce, 2007). That said, future research should examine the effects of positive PsyCap on innovative behaviours within industries where innovation is highly critical for sustainable organizational growth. Finally, longitudinal research designs are vitally important to our understanding of the directions of influence between PsyCap and job outcomes.

\section{JEL Classifications: M1, M12}

\section{References}

Abbas, M., Raja, U., Darr, W., \& Bouckenooghe, D. (2014). Combined effects of perceived politics and psychological capital on job satisfaction, turnover intentions, and performance. Journal of Management 40(7), 1813-1830. doi: 10.1177/ 0149206312455243

Amabile, T.M. (1988). A model of creativity and innovation in organizations. In B.M. Staw, \& L.L. Cummings (Eds.), Research in organizational behavior (vol. 10, pp. 123-167). Greenwich, CT: JAI Press.

Antoniou, A.S., Polychroni, F., \& Vlachakis, A.N. (2006). Gender and age differences in occupational stress and professional burnout between primary and high-school teachers in Greece. Journal of Managerial Psychology, 21(7), 682-690.

Avey, J.M., Luthans, F., \& Jensen, S.M. (2009). Psychological capital: A positive resource for combating employee stress and turnover. Human Resource Management, 48(5), 677-693.

Avey, J.B., Luthans, F., \& Youssef, C.M. (2010). The additive value of positive psychological capital in predicting work attitudes and behaviors. Journal of Management, 36(2), $430-452$.

Avey, J.B., Reichard, R.J., Luthans, F., \& Mhatre, K.H. (2011). Meta-analysis of the impact of positive psychological capital on employee attitudes, behaviors, and performance. Human Resource Development Quarterly, 22(2), 127-152.

Avey, J.B., Wernsing, T.S., \& Luthans, F. (2008). Can positive employees help positive organizational change? Impact of psychological capital and emotions on relevant attitudes and behaviors. The Journal of Applied Behavioral Science, 44(1), 48-70.

Avey, J.B., Wernsing, T.S., \& Mhatre, K.H. (2011). A longitudinal analysis of positive psychological constructs and emotions on stress, anxiety, and well-being. Journal of Leadership \& Organizational Studies, 18(2), 216-228.

Bakker, A.B., \& Demerouti, E. (2008). Towards a model of work engagement. Career Development International, 13(3), 209-223.

Bandura, A. (1986). Social foundations of thought and action: A social cognitive theory. Englewood Cliffs, NJ: Prentice Hall.

Bandura, A. (1991). Social cognitive theory and self-regulation. Organizational Behavior and Human Decision Processes, 50(2), 248-287.

Bandura, A., \& Locke, E.A. (2003). Negative self-efficacy and goal effects revisited. Journal of Applied Psychology, 88(1), 87-99.

Bartram, T., \& Rimmer, M. (2012). Editors' note: Dynamism and diversity in Asian HRM. Asia Pacific Journal of Human Resources, 50(1), 1-5.

Block, J., \& Kremen, A.M. (1996). IQ and ego-resilience: Conceptual and empirical connections and separateness. Journal of Personality and Social Psychology, 70(2), 349-361.

Burton, J.P., Hoobler, J.M., \& Scheuer, M.L. (2012). Supervisor workplace stress and abusive supervision: The buffering effect of exercise. Journal of Business and Psychology, 27(3), 271-279.

Byron, K., Khazanchi, S., \& Nazarian, D. (2010). The relationship between stressors and creativity: A meta-analysis examining competing theoretical models. Journal of Applied Psychology, 95(1), 201-212.

Cameron, K.S., \& Caza, A. (2004). Contributions to the discipline of positive organizational scholarship. American Behavioral Scientist, 47(6), 731-739.

Carson, P.P., \& Carson, K.D. (1993). Managing creativity enhancement through goal-setting and feedback. Journal of Creative Behavior, 27(1), 36-45.

Cartwright, S., \& Cooper, C.L. (1997). Managing workplace stress. Thousand Oaks, CA: Sage.

Cohler, B.J. (1987). Adversity, resilience and the study of lives. In A.E. James, \& B.J. Cohler (Eds.), The invulnerable child (pp. 363-424). New York, NY: Guilford Press.

Combs, G.M., Clapp-Smith, R., \& Nadkarni, S. (2010). Managing BPO service workers in India: Examining hope on performance outcomes. Human Resource Management, 49(3), $457-476$.

Conti, D.J., \& Burton, W.N. (1994). The economic impact of depression in a workplace. Journal of Occupational and Environmental Medicine, 36(9), 983-988.

Coutu, D.L. (2002). How resilience works. Harvard Business Review, 80(3), 46-55.

Damanpour, F. (1991). Organizational innovation: A meta-analysis of effects of determinant and moderators. Academy of Management Journal, 34(3), 555-590. 
Drazin, R., \& Schoonhoven C.B. (1996). Community, population, and organization effects on innovation: A multilevel perspective. Academy of Management Journal, 39(5), 1065-1083.

Fredrickson, B.L. (2001). The role of positive emotions in positive psychology: The broaden-and-build theory of positive emotions. American Psychologist, 56(3), 218-226.

Fredrickson, B.L. (2004). The broaden-and-build theory of positive emotions. Philosophical Transactions of the Royal Society, B: Biological Sciences, 359 (1449), 1367-1377. doi:10.1098/ rstb.2004.1512

Furnham, A., \& Bachtiar, V. (2008). Personality and intelligence as predictors of creativity. Personality and Individual Differences, 45(7), 613-617.

Greenberg, P.E., Kessler, R.C., Birnbaum, H.G., Leong, S.A., Lowe, S.W., Berglund, P.A., \& Corey-Lisle, P.K. (2003). The economic burden of depression in the United States: How did it change between 1990 and 2000? Journal of Clinical Psychiatry, 64(12), 1465-1475.

Hambrick, D.C. (2007). The field of management's devotion to theory: Too much of a good thing? Academy of Management Journal, 50(6), 1346-1352.

Hobfoll, S.E. (2002). Social and psychological resources and adaptation. Review of General Psychology, 6(4), 307-324.

Hunter, L.W., \& Thatcher, S.M. (2007). Feeling the heat: Effects of stress, commitment, and job experience on job performance. Academy of Management Journal, 50(4), 953-968.

Isen, A.M. (1999). On the relationship between affect and creative problem solving. In S. Russ (Ed.), Affect, creative experience, and psychological adjustment (pp.3-17). Philadelphia, PA: Brunner/Mazel.

Isen, A.M. (2000). Some perspectives on positive affect and selfregulation. Psychological Inquiry, 11(3), 184-187.

Kahn, B.E., \& Isen, A.M. (1993). The influence of positive affect on variety seeking among safe, enjoyable products. Journal of Consumer Research, 20(2), 257-270.

Jamal, M. (2007). Job stress and job performance controversy revisited: An empirical examination in two countries. International Journal of Stress Management, 14(2), 175-187.

Jamal, M. (2010). Burnout among Canadian, Chinese, Malaysian and Pakistani employees: An empirical examination. International Management Review, 6(1), 31-41.

Jamal, M., \& Baba, V.V. (1992). Shift work and department-type related to job stress, work attitudes and behavioral intentions: A study of nurses. Journal of Organizational Behavior, 13(5), 449-464.

Janssen, O. (2001). Fairness perceptions as a moderator in the curvilinear relationships between job demands, and job performance and job satisfaction. Academy of Management Journal, 44(5), 1039-1050.

Janssen, O. (2004). How fairness perceptions make innovative behavior more or less stressful. Journal of Organizational Behavior, 25(2), 201-215.

Kanter, R.M. (1988). When a thousand flowers bloom: Structural, collective, and social conditions for innovation in organizations. In B.M. Staw, \& L.L. Cummings (Eds.), Research in organizational behavior (vol. 10, pp. 169-211). Greenwich, CT: JAI Press.

Kluemper, D.H., Little, L.M., \& DeGroot, T. (2009). State or trait: Effects of state optimism on job-related outcomes. Journal of Organizational Behavior, 30(2), 209-231.
Lau, S., \& Cheung, P.C. (2010). Developmental trends of creativity: What twists of turn do boys and girls take at different grades? Creativity Research Journal, 22(3), 329-336.

Luthans, F., Avey, J.B., \& Patera, J.L. (2008). Experimental analysis of a web-based intervention to develop positive psychological capital. Academy of Management Learning and Education, 7(2), 209-221.

Luthans, F., Avolio, B.J., Avey, J.B., \& Norman, S.M. (2007). Psychological capital: Measurement and relationship with performance and satisfaction. Personnel Psychology, 60(3), 541-572.

Luthans, F., Combs, G., Clapp-Smith R., \& Nadkarni, S. (August, 2006). Knowledge workers in India: Exploring the relationship of hope and optimism with performance. Paper presented at Academy of management annual conference, Atlanta, GA.

Luthans, F., Norman, S.M., Avolio, B.J., \& Avey, J.B. (2008). The mediating role of psychological capital in the supportive organizational climate-employee performance relationship. Journal of Organizational Behavior, 29(2), 219-238.

Luthans, F., \& Youssef, C.M. (2007). Emerging positive organizational behavior. Journal of Management, 33(3), 321-349.

Luthans, F., Youssef, C.M., \& Avolio, B.J. (2007). Psychological capital. New York, NY: Oxford University Press.

Luthans, F., Youssef, C.M., \& Rawski, S.L. (2011). A tale of two paradigms: The impact of psychological capital and reinforcing feedback on problem solving and innovation. Journal of Organizational Behavior Management, 31(4), 333-350.

Lyons, R., Chatman, J., \& Joyce, C. (2007). Innovation in services: Corporate culture and investment banking. California Management Review, 50(1), 174-191.

Magaletta, P.R., \& Oliver, J.M. (1999). The hope construct, will and ways: Their relations with self-efficacy, optimism and well-being. Journal of Clinical Psychology, 55(5), 539-551.

Masten, A.S., \& Reed, M.G.J. (2002). Resilience in development. In C.R. Snyder, \& S.J. Lopez (Eds.), Handbook of positive psychology (pp. 74-88). Oxford, UK: Oxford University Press.

McAdam, R., \& Keogh, W. (2004). Transitioning towards creativity and innovation measurement in SMEs. Creativity and Innovation Management, 13(2), 126-139.

Norman, S.M., Avey, J.B., Nimnicht, J.L., \& Pigeon, N.G. (2010). The interactive effects of psychological capital and organizational identity on employee organizational citizenship and deviance behaviors. Journal of Leadership \& Organizational Studies, 17(4), 380-391.

Oldham, G.R., \& Cummings, A. (1996). Employee creativity: Personal and contextual factors at work. Academy of Management Journal, 39(3), 607-634.

Ong, A.D., Bergeman, C.S., Bisconti, T.L., \& Wallace, K.A. (2006). Psychological resilience, positive emotions, and successful adaptation to stress in later life. Journal of Personality and Social Psychology, 91(4), 730-749.

Parker, D.F., \& DeCotiis, T.A. (1983). Organizational determinants of job stress. Organizational Behavior and Human Performance, 32(2), 160-177.

Peterson, C. (2000). The future of optimism. American Psychologist, 55(1), 44-55.

Peterson, S.J., Walumbwa F.O., Byron, K., \& Myrowitz, J. (2008). CEO positive psychological traits, transformational 
leadership, and firm performance in high-technology start-up and established firms. Journal of Management, 35(2), 348-368.

Pfeffer, J., \& Sutton, R.I. (2006). Hard facts, dangerous half-truths \& total nonsense: Profiting from evidence- based management. Boston, MA: Harvard Business School Press.

Rego, A., Machado, F., Leal, S., \& Cunha, M.P. (2009). Are hopeful employees more creative? An empirical study. Creativity Research Journal, 21(2/3), 223-231.

Rego, A., Sousa, F., \& Marques, C. (2012). Authentic leadership promoting employees' psychological capital and creativity. Journal of Business Research, 65(3), 429-437.

Rego, A., Sousa, F., Marques, C., \& Cunha, M.P. (2012). Optimism predicting employees' creativity: The mediating role of positive affect and the positivity ratio. European Journal of Work and Organizational Psychology, 21(2), 244-270.

Revicki, D.A., \& May, H.J. (1985). Occupational stress, social support, and depression. Health Psychology, 4(1), 61-77.

Robertson, I.T., Cooper, C.L., Williams, J., \& Williams, J. (1990). The validity of the occupational stress indicator. Work \& Stress, 4(1), 29-39.

Salanova, M., Peiró, J.M., \& Schaufeli, W.B. (2002). Self-efficacy specificity and burnout among information technology workers: An extension of the job demand-control model. European Journal of Work and Organizational Psychology, 11(1), 1-25.

Scott, S.G., \& Bruce, R.A. (1994). Determinants of innovative behavior: A path model of individual innovation in the workplace. Academy of Management Journal, 37(3), 580-607.

Seligman, M.E.P. (1998). Learned optimism. New York, NY: Pocket Books.

Seligman, M.E.P., \& Csikszentmihalyi, M. (2000). Positive psychology: An Introduction. American Psychologist, 55(1), 5-14.

Shalley, C.E. \& Gilson, L.L. (2004). What leaders need to know: A review of social and contextual factors that can foster or hinder creativity. The Leadership Quarterly, 15(1), 33-53.

Siu, O.L., Cheung, F., \& Lui, S. (2014). Linking positive emotions to work well-being and turnover intention among Hong Kong police officers: The role of psychological capital. Journal of Happiness Studies, 1-14. doi: 10.1007/s10902-014-9513-8.

Snyder, C.R. (1994). The psychology of hope: You can get there from here. New York, NY: Free Press.

Snyder, C.R., Harris, C., Anderson, J.R., Holleran, S.A., Irving, L.M., Sigmon, S.T., Yoshinobu, L., Gibb, J., Langelle, C., \& Harney, P. (1991). The will and the ways: Development and validation of an individual-differences measure of hope. Journal of Personality and Social Psychology, 60(4), 570-585.

Snyder, C.R., Irving, L., \& Anderson, J. (1991). Hope and health: Measuring the will and the ways. In C.R. Snyder, \& D.R.
Forsyth (Eds.), Handbook of social and clinical psychology (pp. 285-305). Elmsford, NY: Pergamon.

Snyder, C.R., Lapointe, A.B., Crowson, J.J., Jr., \& Early, S. (1998). Preferences of high- and low-hope people for self-referential input. Cognition and Emotion, 12(6), 807-823.

Stajkovic, A., \& Luthans, F. (1998). Self-efficacy and work-related performance: A meta-analysis. Psychological Bulletin, 124(2), 240-261.

Sweetman, D., Luthans, F., Avey, J.B., \& Luthans, B.C. (2011). Relationship between positive psychological capital and creative performance. Canadian Journal of Administrative Sciences, 28(1), 4-13.

Tierney, P., \& Farmer, S.M. (2002). Creative self-efficacy: Potential antecedents and relationship to creative performance. Academy of Management Journal, 45(6), 1137-1148.

Tugade, M.M., \& Fredrickson, B.L. (2004). Resilient individuals use positive emotions to bounce back from negative emotional experiences. Journal of Personality and Social Psychology, 86(2), 320-333.

Wolin, S.J., \& Wolin, S. (1993). Bound and determined: growing up resilient in a troubled family. New York: Villard.

Wright, T.A. 2003. Positive organizational behavior: An idea whose time has truly come. Journal of Organizational Behavior, 24(4), 437-442.

Walumbwa, F.O., Peterson, S.J., Avolio, B.J., \& Hartnell, C.A. (2010). An investigation of the relationships among leader and follower psychological capital, service climate, and job performance. Personnel Psychology, 63(4), 937-963.

Woodman, R.W., Sawyer, J.E., \& Griffin, R.W. (1993). Toward a theory of organizational creativity. Academy of Management Review, 18(2), 293-321.

Wu, C.H., Cheng, Y., Ip, H.M., \& McBride-Chang, C. (2005). Age differences in creativity: Task structure and knowledge base. Creativity Research Journal, 17(4), 321-326.

Youssef, C.M., \& Luthans, F. 2007. Positive organizational behavior in the workplace: The impact of hope, optimism, and resiliency. Journal of Management, 33(5), 774-800.

Yuan, F., \& Woodman, R.W. (2010). Innovative behavior in the workplace: The role of performance and image outcome expectations. Academy of Management Journal, 53(2), 323-342.

Zhong, J., You, J., Gan, Y., Zhang, Y., Lu, C., \& Wang, H. (2009). Job stress, burnout, depression symptoms, and physical health among Chinese university teachers, Psychological Reports, 105(3), 1248-1254.

Zhou, J., \& George, J.M. (2003). Awakening employee creativity: The role of leader emotional intelligence. The Leadership Quarterly, 14(4), 545-568.

Zhou, J., \& Shalley, C.E. 2008. Expanding the scope and impact of organizational creativity research. In J. Zhou, \& C.E. Shalley (Eds.), Handbook of organizational creativity (pp. 347-368). Mahwah, NJ: Erlbaum. 